\title{
Clinical Characteristics and Predictors of Severity of Pediatric Scrub Typhus in a Tertiary Level Hospital in South India
}

\author{
Elayaraja Sivaprakasam (iD ${ }^{1}$, Mahalakshmi Rajan (iD ${ }^{1,}{ }^{*}$, Umapathy Pasupathy (iD) ${ }^{1}$ and Latha \\ Ravichandran (iD ${ }^{1}$ \\ ${ }^{1}$ Department of Pediatrics, Sri Ramachandra Medical College and Research Institute, Chennai, India \\ "Corresponding author: Department of Pediatrics, Sri Ramachandra Medical College and Research Institute, Chennai, India. Tel: +91-19444033296, Email: \\ drmeha12@gmail.com
}

Received 2019 May 29; Revised 2020 January 23; Accepted 2020 January 26.

\begin{abstract}
Background: Scrub typhus, a zoonosis caused by bacteria Orientia tsutsugamushi is associated with varying clinical features and significant mortality due to complication in view of ineffective treatment.

Objectives: This study was undertaken to identify the factors for predicting severity in scrub typhus.

Methods: This retrospective study was conducted at a tertiary care teaching hospital between January 2015 to October 2016 . All children younger than 18 years of age admitted with a history of fever for more than seven days and positive IgM ELISA for scrub typhus were included in the study. Cases of "severe scrub typhus" were identified based on criteria from published pediatric studies. A total of 235 patients tested positive for scrub typhus, out of which 39 patients were in the severe scrub group and 196 in the nonsevere group. Reports were analyzed for the predictors of severity of scrub typhus in both groups.

Results: Using multivariate analysis, the factors for predicting severity in scrub typhus were hemoglobin $<10 \mathrm{~g} / \mathrm{L}(\mathrm{OR}=2.8, \mathrm{CI}=1.40$ to 5.72), platelet $<150000$ cells $/ \mathrm{mm}^{3}$ ( $\mathrm{OR}=2.54, \mathrm{CI}=1.21$ to 5.30$)$, albumin $<2.5 \mathrm{~g} / \mathrm{d}(\mathrm{OR}=3.18, \mathrm{CI}=1.42$ to 7.11$)$, SGOT $>5$ fold rise (OR $=49.7, \mathrm{CI}=13.49$ to 183.17), prolongation of PT $(\mathrm{P}$ value $=0.03)$, and altered sensorium $(\mathrm{P}$ value $=0.016)$ were correlated with severe disease.

Conclusions: We conclude that altered sensorium, anemia, thrombocytopenia, elevated transaminases, hypoalbuminemia, and prolongation of prothrombin time to be predictors of severity of illness in scrub typhus.
\end{abstract}

Keywords: Scrub Typhus, Laboratory Markers, Clinical Markers

\section{Background}

Scrub typhus is a common bacterial zoonosis caused by a Gram-negative bacterium known as Orientia tsutsugamushi. This infection is transmitted to humans from the bite of a trombiculid mite (1). It was originally found in the Himalayan foothills and Southeast Asia, whereas it has now spread to different parts of India, with higher incidence rates reported in southern and northeastern regions of the country. The tsutsugamushi triangle, which comprises of Southeast Asia, Asian Pacific Rim, and Northern Australia, accounts for the largest burden of the disease $(1,2)$. Although it was considered to be a rare disease for decades and practically obsolete after the Second World War (3), there has been a clear re-emergence of the disease in many parts of India and Burma.

The clinical manifestations of scrub typhus are attributed to acute vasculopathy that ensues when the organism attaches to and penetrates into phagocytes and endothelial cells by a specific 56-KDA protein. Fever, headache, drowsiness, conjunctival suffusion, lymphadenopathy, and hepatosplenomegaly are the common clinical manifestations of scrub typhus. A characteristic eschar can be seen at variable rates (10\% - 92\%) at the site of the chigger bite (4). Severe complications include septic shock, acute kidney injury, meningoencephalitis, myocarditis, disseminated intravascular coagulation (DIC), and multi-organ dysfunction syndrome, which may occur in a variable number of patients.

It is known that diagnostic tests for scrub typhus, such as Weil-Felix test, lack sensitivity and specificity. In India, the current serological diagnostic test continues to be immunoglobulin M enzyme-linked immunosorbent assay (IgM ELISA), as the gold standard immunofluorescence antibody (IFA) kit is not readily available in the country. Although the majority of previous studies have emphasized on the clinical aspects of this disease, there are insufficient 
studies on markers of its severity (5). Therefore, it is important to study the markers of disease severity, which can predict the clinical course and complications and facilitate early treatment.

\section{Objectives}

In this retrospective study, we aimed to present a detailed clinical profile of scrub typhus and identify the predictors of its severity.

\section{Methods}

This retrospective study was conducted at Sri Ramachandra Medical College and Research Institute, Chennai, India from January 2015 to November 2017. Children who were clinically symptomatic and positive for scrub typhus IgM were included in the analysis. Data were collected from a detailed proforma, which contained clinical details and laboratory reports of patients, including complete blood cell count, liver function tests, kidney function tests, serum electrolytes, routine urine tests, scrub typhus IgM, and other relevant examinations.

Scrub typhus was diagnosed based on major clinical symptoms including acute fever and at least one of the minor symptoms, such as myalgia, headache, conjunctival injection, cough, profuse sweating, maculopapular rash, lymphadenopathy, eschar, and positive IgM ELISA results (6). The exclusion criteria in this study were as follows: children using long-term medications, immunodeficiency, and have a chronic disease. Severity of the disease was defined based on previously published adult and pediatric studies (7-13). The study population was divided into two groups in terms of disease severity: (1) non-severe, patients without any complications and (2) severe, patients with severe complications. Out of 235 patients who tested positive for scrub typhus, 39 were classified in the severe group and 196 in the non-severe group.

\subsection{Definition of Severe Scrub Typhus}

Severe scrub typhus was diagnosed in patients with a clinical image of organ dysfunction (Table 1).

\subsection{Statistical Analysis}

Categorical data are expressed as frequency. Differences between the two groups were analyzed using chisquare test. Multivariate logistic regression analysis and chi-square test were performed to determine the associations between variables and severity of disease for predicting the severity of scrub typhus. The final data are presented as unadjusted odds ratio (OR) at 95\% confidence interval (CI). P value less than 0.05 was considered statistically significant. Statistical analyses were performed in SPSS version 23.0 (SPSS Inc., Chicago, Ill., USA).

\section{Results}

A total of 235 patients were included in this study. The study population was divided into two groups of severe and non-severe scrub typhus, based on the defined criteria. Clinical parameters were compared between the two groups (Table 2). According to multivariate regression analysis, some parameters were found to be strong predictors of the severity of the disease.

Approximately $20 \%$ of children with scrub typhus below 10 years of age developed the severe form of the disease versus $12 \%$ of children in the age group of 10 - 18 years. Younger patients seem to be more susceptible to severe scrub typhus, compared to older children, as they are actively involved in recreational activities, associated with higher outdoor exposure.

The findings showed that more than $50 \%$ of patients in the severe scrub typhus group required PICU stay versus $10.2 \%$ of patients in the non-severe group. The most common reasons for PICU stay were hemodynamic instability and organ dysfunction. Only $20 \%$ of the patients developed eschar, and the difference between the two groups was not significant. Gastrointestinal (GI) involvement was reported in $23.1 \%$ of children with severe scrub typhus versus only $8.7 \%$ in the non-severe group, presenting with diarrhea.

Moreover, $33.4 \%$ of children with severe scrub typhus showed symptoms of central nervous system (CNS) involvement (e.g., altered sensorium and seizures) versus < $2 \%$ in the non-severe group.

Based on the findings, there was no significant difference between the two groups with regard to clinical parameters, such as sex, jaundice, cough, myalgia, dyspnea, oliguria, vomiting, hepatomegaly, splenomegaly, abdominal pain, headache, rash, and edema.

Comparison of laboratory parameters (Table3) showed that the hemoglobin level was significantly different between the two groups $(\mathrm{P}<0.005)$, and the severe scrub typhus group had lower hemoglobin levels. Comparison of platelet count showed a significant difference between the two groups $(\mathrm{P}<0.001)$, although its clinical relevance was minimal. On average, platelet count in the severe scrub typhus group was lower than that of the non-severe group.

According to the liver function tests, liver enzymes (SGOT and SGPT) were found to be markedly higher in patients with severe scrub typhus. The average levels of SGOT and SGPT in the severe scrub typhus group were more than five times higher than the average SGOT and SGPT in 


\begin{tabular}{|c|c|c|}
\hline Involved Organs & Complications & Clinical Definition \\
\hline \multirow{2}{*}{ Respiratory system } & Acute respiratory distress syndrome & $\begin{array}{l}\mathrm{PaO}_{2} / \mathrm{FiO}_{2} \text { ratio } \leq 200 \mathrm{mmHg} \text {; bilateral infiltrates on a chest radiograph; no } \\
\text { evidence of left-sided heart failure/cardiomegaly }\end{array}$ \\
\hline & Pneumonia & Clinical and radiological evidence of pneumonia \\
\hline \multirow{2}{*}{ Cardiovascular system } & Myocarditis & $\begin{array}{l}\text { Congestive heart failure/cardiomegaly; Inotrope requirement }>5 \mu \mathrm{g} / \mathrm{kg} / \mathrm{min} \\
\text { (dopamine/dobutamine); left ventricular dysfunction based on the } \\
\text { echocardiogram without a history of cardiomyopathy; elevated serum MB } \\
\text { fraction of creatine phosphokinase; abnormal electrocardiography }\end{array}$ \\
\hline & Shock & $\begin{array}{l}\text { Reduction of blood pressure (hypotension) }<5 \text { th percentile for age, sex, and } \\
\text { height or systolic blood pressure }<2 \text { SD below the normal range for age; fluid } \\
\text { refractory shock requiring inotropes }\end{array}$ \\
\hline Blood parameters & $\begin{array}{l}\text { Severe thrombocytopenia and bleeding } \\
\text { tendency }\end{array}$ & $\begin{array}{l}\text { Platelet count }<20,000 / \mathrm{mm}^{3} ; \text { spontaneous bleeding tendency; increased } \\
\text { prothrombin time }\end{array}$ \\
\hline \multirow{2}{*}{ Abdominal system } & Acute kidney injury & $\begin{array}{l}\text { Absolute increase in serum creatinine } \geq 0.3 \mathrm{mg} / \mathrm{dL}(\geq 26.4 \mathrm{~mol} / \mathrm{L}) ; \text { percentage } \\
\text { increase in serum creatinine } \geq 50 \% \text { ( } 1.5 \text { fold from baseline); reduction of urine } \\
\text { output (documented oliguria }<0.5 \mathrm{~mL} / \mathrm{kg} \text { per hour for more than six hours) }\end{array}$ \\
\hline & Hepatic dysfunction & $\begin{array}{l}\text { More than a four-fold increase in liver transaminases with or without bilirubin } \\
>2 \mathrm{mg} / \mathrm{dL}\end{array}$ \\
\hline Central nervous system & Meningoencephalitis & $\begin{array}{l}\text { Neurological symptoms including headache, altered sensorium, seizure, and } \\
\text { vomiting with; meningeal signs, papilledema or; CSF analysis indicating } \\
\text { pleocytosis and elevated protein level }\end{array}$ \\
\hline
\end{tabular}

Table 2. Clinical Characteristics of Patients with Severe and Non-Severe Scrub Typhus ${ }^{\mathrm{a}}$

\begin{tabular}{|c|c|c|c|}
\hline Characteristics & $\begin{array}{l}\text { Severe Scrub } \\
\text { Typhus }(N=39)\end{array}$ & $\begin{array}{l}\text { Non-Severe Scrub } \\
\text { Typhus ( }=196)\end{array}$ & PValue \\
\hline Age, $y$ & & & 0.190 \\
\hline$<5$ & $19(48.7)$ & $67(34.2)$ & \\
\hline $6-10$ & $8(20.5)$ & $42(21.4)$ & \\
\hline $11-18$ & $12(30.8)$ & $87(44.4)$ & \\
\hline Gender & & & 0.160 \\
\hline Male & $16(41)$ & $107(54.6)$ & \\
\hline Female & $23(59)$ & $89(45.4)$ & \\
\hline PICU stay & $20(51.3)$ & $20(10.2)$ & $<0.001$ \\
\hline Fever & $38(97.4)$ & $193(98.5)$ & 0.519 \\
\hline Myalgia & $2(5.1)$ & $26(13.3)$ & 0.185 \\
\hline Eschar & $10(25.6)$ & $42(21.4)$ & 0.534 \\
\hline Jaundice & $1(2.6)$ & $3(1.5)$ & 0.519 \\
\hline Cough & $12(30.8)$ & $59(30.1)$ & 1.00 \\
\hline Dyspnea & $4(10.3)$ & $7(3.6)$ & 0.089 \\
\hline Oliguria & $6(15.4)$ & $26(13.3)$ & 0.798 \\
\hline Vomiting & $13(23.3)$ & $60(30.6)$ & 0.710 \\
\hline Diarrhea & $9(23.1)$ & $17(8.7)$ & 0.021 \\
\hline Hepatomegaly & $3(7.7)$ & $23(11.7)$ & 0.585 \\
\hline Splenomegaly & $4(10.3)$ & $31(15.8)$ & 0.467 \\
\hline $\begin{array}{l}\text { Altered } \\
\text { sensorium }\end{array}$ & $4(10.3)$ & $3(1.5)$ & 0.016 \\
\hline Abdominal pain & $11(28.2)$ & $37(18.9)$ & 0.196 \\
\hline Seizure & $9(23.1)$ & $0(0)$ & $<0.001$ \\
\hline
\end{tabular}

${ }^{\mathrm{a}}$ Values are expressed as No. (\%).

\begin{tabular}{|c|c|c|c|}
\hline Characteristics & $\begin{array}{c}\text { Severe Scrub } \\
\text { Typhus }(\mathrm{N}=\mathbf{3 9})\end{array}$ & $\begin{array}{c}\text { Non-Severe Scrub } \\
\text { Typhus }(\mathrm{N}=196)\end{array}$ & P Value \\
\hline $\begin{array}{l}\text { Hemoglobin, } \\
\text { g/dL }\end{array}$ & $9.91 \pm 1.44$ & $10.74 \pm 1.68$ & 0.005 \\
\hline Total count, $\mathbf{m m}^{3}$ & $10643.05 \pm 4971.17$ & $10111.31 \pm 5385.55$ & 0.339 \\
\hline $\begin{array}{l}\text { Platelet count, } \\
\mathrm{mm}^{3}\end{array}$ & $149143.59 \pm 4971.17$ & $\begin{array}{c}199362.24 \pm \\
108252.91\end{array}$ & $<0.001$ \\
\hline $\begin{array}{l}\text { Blood urea } \\
\text { nitrogen, } \mathrm{mg} / \mathrm{dL}\end{array}$ & $12.31 \pm 18.19$ & $9.60 \pm 5.01$ & 0.387 \\
\hline $\begin{array}{l}\text { Creatinine, } \\
\mathrm{mg} / \mathrm{dL}\end{array}$ & $0.71 \pm 0.69$ & $0.67 \pm 0.28$ & 0.095 \\
\hline Sodium, mEq/L & $136.9 \pm 6.1$ & $135.8 \pm 8.3$ & 0.461 \\
\hline Potassium, mEq/L & $3.83 \pm 0.76$ & $3.78 \pm 0.71$ & 0.661 \\
\hline $\begin{array}{l}\text { Total bilirubin, } \\
\text { mg/dL }\end{array}$ & $0.72 \pm 0.70$ & $0.54 \pm 0.48$ & 0.056 \\
\hline $\begin{array}{l}\text { Direct bilirubin, } \\
\mathrm{mg} / \mathrm{dL}\end{array}$ & $0.46 \pm 0.59$ & $0.25 \pm 0.28$ & 0.001 \\
\hline $\begin{array}{l}\text { Serum glutamic } \\
\text { oxaloacetic } \\
\text { transaminase } \\
\text { (SGOT), IU/L }\end{array}$ & $204.1 \pm 143.1$ & $65.1 \pm 43.3$ & $<0.001$ \\
\hline $\begin{array}{l}\text { Serum glutamic } \\
\text { pyruvic } \\
\text { transaminase } \\
\text { (SGPT), IU/L }\end{array}$ & $167 \pm 145.6$ & $50.8 \pm 26.1$ & $<0.001$ \\
\hline $\begin{array}{l}\text { Serum albumin, } \\
\text { g/dL }\end{array}$ & $3.07 \pm 0.72$ & $3.37 \pm 0.62$ & 0.007 \\
\hline
\end{tabular}

${ }^{\mathrm{a}}$ Values are expressed as mean $\pm \mathrm{SD}$. 
the non-severe group. The bilirubin level, serum albumin, prothrombin time, and partial thromboplastin time were compared between the two groups, and the difference was statistically significant.

Multivariate regression analysis was conducted to compare the laboratory findings of the two groups (Table 4). Comparisons showed the deterioration of different parameters in the group with severe scrub typhus. Serum albumin was markedly lower in patients with severe scrub typhus. The number of patients with serum albumin levels below $2.5 \mathrm{~g} / \mathrm{dL}$ was lower in the severe scrub typhus group, compared to the non-severe group $(\mathrm{OR}=3.185 ; \mathrm{CI}=1.427$ to 7.110; $\mathrm{P}=0.006)$. The findings showed that the SGOT level was significantly higher in the severe scrub typhus group, compared to the non-severe group $(\mathrm{OR}=49.7 ; \mathrm{CI}=13.490$ to 183.179; $\mathrm{P}<0.001)$. According to the results, despite the increased enzyme levels of patients with severe scrub typhus, none of them experienced hepatic failure.

Based on the results, the average platelet count was lower in the severe scrub typhus group, compared to the non-severe group. Comparison of the number of patients with thrombocytopenia ( $<150,000$ cells/cumm) between the two groups showed that most patients belonged to the severe scrub typhus group ( $\mathrm{OR}=2.543 ; \mathrm{CI}=1.219$ to 5.307; $\mathrm{P}=0.014)$. Moreover, comparison of patients with hemoglobin levels below $10 \mathrm{~g} / \mathrm{dL}$ showed that most of these patients belonged to the severe scrub typhus group $(\mathrm{OR}=$ 2.831; $\mathrm{CI}=1.401$ to $5.722 ; \mathrm{P}=0.004)$.

According to the odds ratio measurements, other significant parameters included altered sensorium, blood urea nitrogen level, creatinine level, and PICU stay. These parameters were expected to be higher in patients with severe scrub typhus. In addition, comparison of clinical presentations showed that the incidence of diarrhea was higher among patients with severe scrub typhus (OR = 3.159; $\mathrm{CI}=1.290$ to $7.736 ; \mathrm{P}=0.02$ ).

Table 5 presents the complications of patients with scrub typhus. The incidence of complications was reported in comparison with the total number of patients without the complication, to prevent any untoward bias related to patients with multiple complications. A total of 235 patients presented with scrub typhus, 38 of whom experienced difficulties. Shock was the most common complication, as reported in 16 patients ( $6.8 \%$ of the study population), followed by renal failure (2.1\%) and seizure (2.1\%). The mortality rate was $1.3 \%$ in our population, which is similar to the rate reported by Kim et al., (0.5\%) (11).

\section{Discussion}

In this study, we collected the data of 235 patients with scrub typhus over three years and analyzed the results.
The proportion of patients with severe scrub typhus was $16.6 \%$, which is lower than the rate reported by Kim et al. (11), (42.8\%). On the other hand, two studies from India reported higher rates than our study. A study by Karanth et al. (14), from Karnataka, India, demonstrated that 52.7\% of patients had severe scrub typhus, while another study from Pondicherry reported a prevalence of $40.6 \%$. In the study by Karanth et al. (14), the number of patients with severe scrub typhus was higher in younger age groups, while the incidence of severe scrub typhus was lower in children above five years. The possible reason for this finding may be the robust immune system of older children, compared to the younger age groups.

In the present study, only $22.13 \%$ of the patients presented with eschar. There was no significance difference between the two groups with regard to eschar. In this regard, Karanth et al. (14), reported eschar in $40.38 \%$ of patients in the non-severe group. Conversely, in the study by Narayanasamy et al. (15), only $25 \%$ of patients with severe scrub typhus developed eschar. Kim et al. (11), reported that the absence of eschar is one of the predictors of disease severity in adults. Based on these findings, no clear evidence suggests that eschar is one of the predictors of disease severity. The causes of difference between these studies may be the location of the study populations, clinical knowledge of physicians about eschar, and earlier detection of eschar in febrile patients. The lower prevalence of eschar could be attributed to the dark skin color of the Indian population and the unusual feeding sites of chiggers $(16,17)$.

In the present study, the proportion of patients with GI symptoms was much higher in the severe group, whereas no such association was found in previous studies. Therefore, further studies are needed to support this association. In the present study, $1.7 \%$ of the patients had meningoencephalitis, whereas Narayanasamy et al. (15), showed a higher incidence rate (9\%). The pathognomonic sign of this disease is the presence of organisms in CSF due to invasion and inflammation of leptomeninges. Although many studies have documented GI involvement in scrub typhus, the exact cause remains unclear.

Neurological symptoms, such as altered sensorium, were found to be more prevalent in children, which might be due to dyselectrolytemia, hypoxia, sepsis, and hypoglycemia. Moreover, $43.6 \%$ of children had elevation of SGOT fivefold $(\mathrm{P}<0.001)$, whereas there was no case of hepatitis, probably due to mild portal inflammation, without causing significant hepatitis. The main causes of CNS involvement in scrub typhus were direct invasion of organisms across the cerebrospinal fluid (CSF) barrier and small vessel vasculitis changes in the meninges (18).

The serum albumin level was low in patients with se- 


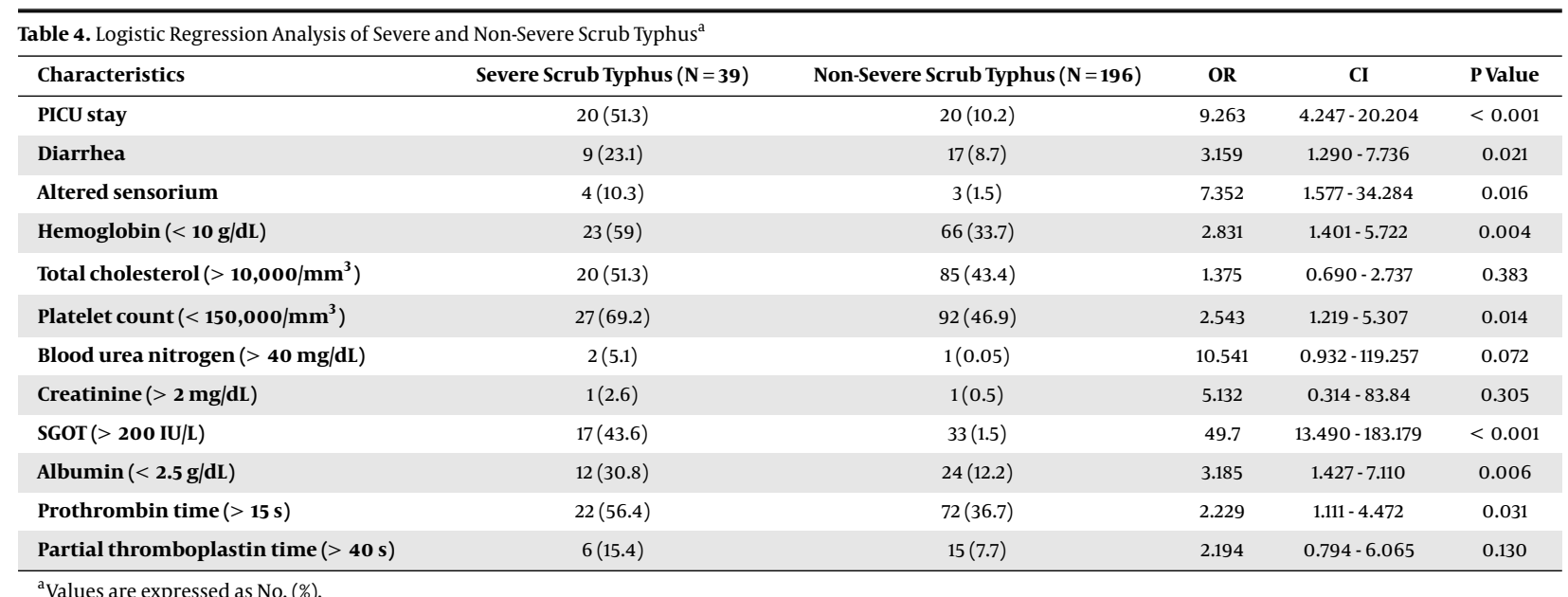

\begin{tabular}{lcc}
\hline \multicolumn{2}{l}{ Table 5. Complications of Children with Scrub Typhus } & \\
\hline Complications & Absent & Present \\
\hline Pneumonia & $233(97.9)$ & $2(0.9)$ \\
\hline Renal failure & $230(97.9)$ & $5(2.1)$ \\
\hline Coagulopathy & $233(99.1)$ & $2(0.9)$ \\
\hline DIC & $233(99.1)$ & $2(0.9)$ \\
\hline Shock & $219(93.2)$ & $16(6.8)$ \\
\hline Myocarditis & $233(99.1)$ & $1(0.4)$ \\
\hline Hepatic failure & $235(100)$ & 0.0 \\
\hline Meningoencephalitis & $231(98.3)$ & $4(1.7)$ \\
\hline Seizure & $230(97.9)$ & $5(2.1)$ \\
\hline Multiple organ dysfunction syndrome & $234(99.6)$ & $1(0.4)$ \\
\hline Death & $232(98.7)$ & $3(1.3)$ \\
\hline a Values are expressed as & & \\
\hline
\end{tabular}

${ }^{\mathrm{a}}$ Values are expressed as No. (\%).

vere scrub typhus ( $\mathrm{OR}=3 ; \mathrm{CI}=1.427$ to $7.110 ; \mathrm{P}<0.006)$, which is probably due to increased capillary leakage from blood vessels, leading to hypoalbuminemia $(19,20)$. This association seems to be an independent risk factor for the severity of disease, as demonstrated by Lee at al. (21), and Kim et al. (20). In our study $69.2 \%$ of patients with severe scrub typhus had thrombocytopenia with platelet counts below 1.5 lakh/cumm. However, in the present study, there was no cut-off point for severe thrombocytopenia, unlike other studies. In addition, the results showed that $59 \%$ of patients with severe scrub typhus had anemia $(\mathrm{Hb}<10$ $\mathrm{g} / \mathrm{dL}$ ). Karanth et al. (14), also found that $47.4 \%$ of patients had anemia, which is one of the predictors of disease severity $(\mathrm{Hb}<12 \mathrm{~g} / \mathrm{dL})$. Nevertheless, Kim et al., could not find such an association.

The mortality rate was $1.3 \%$ in our population, which is similar to the rate reported by Kim et al. (11), (0.5\%). On the other hand, Varghese et al. (5), reported a mortality rate of $14 \%$ from India, and Watt et al. , reported a mortality rate of
$15 \%$ - 30\% from Thailand.

Based on the analysis of studies on the severity of scrub typhus (Table 6), some parameters were found to be common, including anemia, thrombocytopenia, and hypoalbuminemia, while other parameters, such as age, leukocytosis, eschar, multi-organ dysfunction syndrome, and serum creatinine could not be compared, most likely due to the insignificant number of cases. It was concluded that low hemoglobin level, thrombocytopenia, transaminitis, low albumin level, and prolongation of prothrombin time were the major predictors of scrub typhus severity in the present study.

\subsection{Limitations}

First, since the rate of mortality was low, it was not possible to determine the risk factors for mortality. Second, it was not possible to determine the serotypes of scrub typhus, and therefore, the association between disease severity and genotypes was not evaluated. Third, considering the retrospective design of this study, it was not possible to identify other co-infections. Finally, diagnoses were clinically established based on serological tests, and they were not confirmed by the gold standard test (PCR assay).

\subsection{Conclusions}

The predictors of disease severity in the present study were anemia, hypoalbuminemia, thrombocytopenia, prolongation of prothrombin time, elevation of SGOT, and GI symptoms. The presence of one or more of these clinical and biochemical markers should raise the physician's suspicion about the severity of the disease, warranting immediate and comprehensive treatment in view of the possible complications and highlighting the need for parental counseling about the disease. 


\begin{tabular}{|c|c|c|c|c|c|c|c|}
\hline Authors & Journals & $\begin{array}{l}\text { Number of } \\
\text { Patients }\end{array}$ & $\begin{array}{c}\text { Number of } \\
\text { Severe }\end{array}$ & $\begin{array}{l}\text { Number of } \\
\text { Non-Severe }\end{array}$ & $\begin{array}{c}\text { Severity } \\
\text { Predictors }\end{array}$ & Odds Ratio & PValue \\
\hline \multirow{5}{*}{ Narayanasamy et al. (15) } & \multirow{5}{*}{$\begin{array}{c}\text { Indian } \\
\text { Journal of } \\
\text { Pediatrics }\end{array}$} & \multirow{5}{*}{230} & \multirow{5}{*}{91} & \multirow{5}{*}{133} & Breathlessness & $\begin{array}{l}\text { Breathlessness (OR } \\
=6.85 ; 95 \% \mathrm{CI}=2.69 \\
-9.87)\end{array}$ & 0.009 \\
\hline & & & & & Altered sensorium & $\begin{array}{l}\text { Altered sensorium } \\
(\mathrm{OR}=11.48 ; 95 \% \mathrm{CI}= \\
3.43-10.19)\end{array}$ & 0.001 \\
\hline & & & & & Leukocytosis & $\begin{array}{l}\text { Leukocytosis }(\mathrm{OR}= \\
3.38 ; 95 \% \mathrm{CI}=1.12- \\
10.16)\end{array}$ & 0.03 \\
\hline & & & & & Hypoalbuminemia & $\begin{array}{l}\text { Hypoalbuminemia } \\
(\mathrm{OR}=10.78 ; 95 \% \mathrm{CI}= \\
2.66-48.76)\end{array}$ & 0.001 \\
\hline & & & & & Hyponatremia & $\begin{array}{l}\text { Hyponatremia (OR } \\
=10.08 ; 95 \% \mathrm{CI}=2.11 \\
-23.42)\end{array}$ & 0.001 \\
\hline \multirow{6}{*}{$\begin{array}{l}\text { Pamornsrisriwongpan } \\
\text { et al. }\end{array}$} & \multirow{6}{*}{$\begin{array}{l}\text { Clinical } \\
\text { Risk-Scoring } \\
\text { Algorithm to } \\
\text { Forecast } \\
\text { Scrub Typhus } \\
\text { Severity }\end{array}$} & \multirow{6}{*}{526} & \multirow{6}{*}{100} & \multirow{6}{*}{357} & Age $<15$ years & Age $(\mathrm{OR}=4.09)$ & $<0.001$ \\
\hline & & & & & Pulse rate & Pulse rate $(\mathrm{OR}=3.19)$ & $<0.001$ \\
\hline & & & & & Crepitation & $\begin{array}{l}\text { Crepitation }(\mathrm{OR}= \\
2.97)\end{array}$ & $<0.001$ \\
\hline & & & & & $\begin{array}{l}\text { Serum aspartate } \\
\text { aminotransferase } \\
\text { level > } 60 \mathrm{IU} / \mathrm{L}\end{array}$ & $\begin{array}{l}\text { Serum aspartate } \\
\text { aminotransferase } \\
(\mathrm{OR}=2.89)\end{array}$ & $<0.001$ \\
\hline & & & & & $\begin{array}{c}\text { Serum albumin }< \\
3.0 \mathrm{~g} / \mathrm{dL}\end{array}$ & $\begin{array}{l}\text { Serum albumin (OR } \\
=4.69)\end{array}$ & $<0.001$ \\
\hline & & & & & $\begin{array}{c}\text { Serum creatinine }> \\
1.4 \mathrm{mg} / \mathrm{dL}\end{array}$ & $\begin{array}{l}\text { Serum creatinine } \\
(\mathrm{OR}=8.19)\end{array}$ & $<0.001$ \\
\hline \multirow{4}{*}{ Kim et al. (11) } & \multirow{4}{*}{$\begin{array}{c}\text { BMC } \\
\text { Infectious } \\
\text { Diseases }\end{array}$} & \multirow{4}{*}{333} & \multirow{4}{*}{89} & \multirow{4}{*}{119} & Age $>60$ years, & $\begin{array}{l}\text { Age }>60 \text { years }(\mathrm{OR} \\
=3.13)\end{array}$ & 0.002 \\
\hline & & & & & Absence of eschar, & $\begin{array}{l}\text { Absence of eschar } \\
(\mathrm{OR}=6.62)\end{array}$ & 0.03 \\
\hline & & & & & $\mathrm{WBC}>10,000 / \mathrm{mm}^{3}$ & $\begin{array}{l}\mathrm{WBC}>10,000 / \mathrm{mm} 3 \\
(\mathrm{OR}=3.6)\end{array}$ & 0.001 \\
\hline & & & & & $\begin{array}{l}\text { Serum albumin } \\
\text { level }<3 \mathrm{~g} / \mathrm{dL}\end{array}$ & $\begin{array}{l}\text { Serum albumin }<3 \\
\mathrm{~g} / \mathrm{dL}(\mathrm{OR}=5.01)\end{array}$ & 0.004 \\
\hline \multirow{5}{*}{ Varghese et al. (5) } & \multirow{5}{*}{$\begin{array}{l}\text { International } \\
\text { Journal of } \\
\text { Infectious } \\
\text { Diseases }\end{array}$} & \multirow{5}{*}{623} & \multirow{5}{*}{212} & \multirow{5}{*}{411} & $\begin{array}{l}\text { Hypotension } \\
\text { requiring } \\
\text { inotropes, }\end{array}$ & $\begin{array}{l}\text { Hypotension } \\
\text { requiring inotropes } \\
(\mathrm{OR}=10.1)\end{array}$ & $<0.001$ \\
\hline & & & & & $\begin{array}{c}\text { Creatinine }>2 \\
\mathrm{mg} / \mathrm{dL}\end{array}$ & $\begin{array}{l}\text { Creatinine }>2 \\
\mathrm{mg} / \mathrm{dL}(\mathrm{OR}=3.5)\end{array}$ & 0.001 \\
\hline & & & & & CNS dysfunction & $\begin{array}{l}\text { CNS dysfunction } \\
(\mathrm{OR}=6)\end{array}$ & $<0.001$ \\
\hline & & & & & $\begin{array}{c}\text { Bilirubin level }>2 \\
\mathrm{mg} / \mathrm{dL}\end{array}$ & $\begin{array}{l}\text { Bilirubin }>2 \mathrm{mg} / \mathrm{dL} \\
(\mathrm{OR}=1.4)\end{array}$ & 0.36 \\
\hline & & & & & Ventilation & $\begin{array}{l}\text { Ventilation }(\mathrm{OR}= \\
2.2)\end{array}$ & 0.14 \\
\hline \multirow{4}{*}{ Karanth et al. (14) } & \multirow{4}{*}{$\begin{array}{l}\text { Asian Pacific } \\
\text { Journal of } \\
\text { Tropical } \\
\text { Disease }\end{array}$} & \multirow{4}{*}{220} & \multirow{4}{*}{116} & \multirow{4}{*}{104} & $\begin{array}{c}\text { Hemoglobin }<12 \\
\text { g/dL }\end{array}$ & $\begin{array}{l}\text { Hemoglobin }<12 \\
\text { g/dL }(\mathrm{OR}=2)\end{array}$ & 0.037 \\
\hline & & & & & $\begin{array}{l}\text { WBC }>10,000 \\
\text { cells } / \mathrm{mm}^{3}\end{array}$ & $\begin{array}{l}\text { WBC }>10,000 \\
\text { cells } / \mathrm{mm}^{3}(\mathrm{OR}=3)\end{array}$ & 0.001 \\
\hline & & & & & $\begin{array}{c}\text { Platelet count }< \\
150,000 \text { cells } / \mathrm{mm}^{3}\end{array}$ & $\begin{array}{l}\text { Platelet }<150000 \\
\text { cell } / \mathrm{mm}^{3}(\mathrm{OR}=6.2)\end{array}$ & $<0.001$ \\
\hline & & & & & Absence of eschar & $\begin{array}{l}\text { Absence of eschar } \\
(\mathrm{OR}=0.4)\end{array}$ & 0.01 \\
\hline
\end{tabular}




\section{Footnotes}

Authors' Contribution: Study design: Mahalakshmi Rajan, Elayaraja Sivaprakasam, Umapathy Pasupathy, and Latha Ravichandran. Data collection: Mahalakshmi Rajan and Elayaraja Sivaprakasam. Analysis and interpretation of the data: Mahalakshmi Rajan and Elayaraja Sivaprakasm. Drafting of the manuscript: Mahalakshmi Rajan. Critical revision of the manuscript: Mahalakshmi Rajan, Elayaraja Sivaprakasam, Umapathy Pasupathy, and Latha Ravichandran. Study supervision: Latha Ravichandran. All authors read and approved the final manuscript.

Conflict of Interests: The authors declare no conflict of interest.

Ethical Approval: The present study was approved by the Sri Ramachandra University and Research Institute.

Funding/Support: The authors declare that there is no funding for the study.

\section{References}

1. Saah AJ, Mandell GL, Bennett JE, Dolin R. Principles and practice of infectious disease. 5th ed. Philadelphia: Churchill Livingstone; 2000. p. 2056-27.

2. World Health Organization. WHO recommended surveillance standards, WHO/ CDS/CSR/ISR/99.2. Geneva: WHO; 2013, [cited 2013 Sep 23]. Available from: http://www.who.int/csr/resources/publications/ surveillance/whocdscsrisr992.pdf.

3. Sayen JJ, Pond HS, Forrester JS, Wood FC. Scrub typhus in Assam and Burma; a clinical study of 616 cases. Medicine (Baltimore).1946;25:155214. doi: 10.1097/00005792-194605000-00003. [PubMed: 20986167].

4. Kim DM, Won KJ, Park CY, Yu KD, Kim HS, Yang TY, et al. Distribution of eschars on the body of scrub typhus patients: A prospective study. Am J Trop Med Hyg. 2007;76(5):806-9. [PubMed: 17488895].

5. Varghese GM, Abraham OC, Mathai D, Thomas K, Aaron R, Kavitha ML, et al. Scrub typhus among hospitalised patients with febrile illness in South India: Magnitude and clinical predictors. Infect. 2006;52(1):5660. doi: 10.1016/j.jinf.2005.02.001. [PubMed: 16368461].

6. World Health Organization. WHO recommended surveillance standards. 2011, [cited 2011 Oct 5]. Available from: http://www.who.int/csr/ resources/publications/surveillance/whocdscsrisr992.pdf.

7. Rathi N, Kulkarni A, Yewale V, For Indian Academy of Pediatrics Guidelines on Rickettsial Diseases in Children C. IAP guidelines on rickettsial diseases in children. Indian Pediatr. 2017;54(3):223-9. doi: 10.1007/s13312-017-1035-0. [PubMed: 28361787].
8. Megan E, Reller J, Dumler S. Scrub typhus (Orientia tsutsugamushi). In: Kliegman RM, editor. Nelson textbook of pediatrics. Philadelphia: Elsevier; 2016. $1504 \mathrm{p}$.

9. Kumar M, Krishnamurthy S, Delhikumar CG, Narayanan P, Biswal N, Srinivasan S. Scrub typhus in children at a tertiary hospital in southern India: Clinical profile and complications. J Infect Public Health. 2012;5(1):82-8. doi: 10.1016/j.jiph.2011.11.001. [PubMed: 22341847].

10. Zhao D, Zhang Y, Yin Z, Zhao J, Yang D, Zhou Q. Clinical predictors of multiple organ dysfunction syndromes in pediatric patients with scrub typhus. J Trop Pediatr. 2017;63(3):167-73. doi: 10.1093/tropej/fmw066. [PubMed: 27697827].

11. Kim DM, Kim SW, Choi SH, Yun NR. Clinical and laboratory findings associated with severe scrub typhus. BMC Infect Dis. 2010;10:108. doi: 10.1186/1471-2334-10-108. [PubMed: 20433689]. [PubMed Central: PMC2877676].

12. Sriwongpan P, Krittigamas P, Kantipong P, Kunyanone N, Patumanond J, Namwongprom S. Clinical indicators for severe prognosis of scrub typhus. Risk Manag Healthc Policy. 2013;6:43-9. doi: 10.2147/RMHP.S52470. [PubMed: 24235852]. [PubMed Central: PMC3826289].

13. Rose W, Ghosh U, Punnen A, Sarkar R, Prakash JJA, Verghese VP. Comparison of scrub typhus with and without meningitis. Indian JPediatr. 2017;84(11):833-7. doi: 10.1007/s12098-017-2403-4. [PubMed: 28674823].

14. Karanth SS, Marupudi KC, Sama VP, Gupta A, Ballal K, Kamath A. Predictors of severity of scrub typhus in the Indian subcontinent. Asian Pac J Trop Dis. 2014;4:S674-8. doi: 10.1016/s2222-1808(14)60705-2.

15. Narayanasamy DK, Arun Babu T, Vijayadevagaran V, Kittu D, Ananthakrishnan S. Predictors of severity in pediatric scrub typhus. Indian J Pediatr. 2018;85(8):613-7. doi: 10.1007/s12098-018-2612-5. [PubMed: 29368107].

16. Wang CC, Liu SF, Liu JW, Chung YH, Su MC, Lin MC. Acute respiratory distress syndrome in scrub typhus. Am JTrop Med Hyg. 2007;76(6):114852. [PubMed: 17556627].

17. John TJ, Dandona L, Sharma VP, Kakkar M. Continuing challenge of infectious diseases in India. Lancet. 2011;377(9761):252-69. doi: 10.1016/S0140-6736(10)61265-2. [PubMed: 21227500].

18. Kularatne SA, Weerakoon KG, Rajapakse RP, Madagedara SC, Nanayakkara D, Premaratna R. A case series of spotted fever rickettsiosis with neurological manifestations in Sri Lanka. Int J Infect Dis. 2012;16(7):e514-7. doi: 10.1016/j.ijid.2012.02.016. [PubMed: 22541336].

19. Seong SY, Choi MS, Kim IS. Orientia tsutsugamushi infection: Overview and immune responses. Microbes Infect. 2001;3(1):11-21. doi: 10.1016/s1286-4579(00)01352-6. [PubMed: 11226850].

20. Kim YO, Yoon SA, Ku YM, Yang CW, Kim YS, Kim SY, et al. Serum albumin level correlates with disease severity in patients with hemorrhagic fever with renal syndrome. J Korean Med Sci. 2003;18(5):696700. doi: 10.3346/jkms.2003.18.5.696. [PubMed: 14555823]. [PubMed Central: РMC3055098].

21. Lee CS, Min IS, Hwang JH, Kwon KS, Lee HB. Clinical significance of hypoalbuminemia in outcome of patients with scrub typhus. BMC Infect Dis. 2010;10:216. doi: 10.1186/1471-2334-10-216. [PubMed: 20646323]. [PubMed Central: PMC2919547]. 